\title{
The British Polio Fellowship: its contribution to the development of inclusivity for disabled people
}

\author{
Barry North (*) \\ (*) Archivist and Historian. British Polio Fellowship. \\ inbox@calshot-mail.co.uk
}

Dynamis

[0211-9536] 2012; $32(2): 361-390$
Fecha de recepción: 1 de septiembre de 2011

Fecha de aceptación: 8 de noviembre de 2011

SUMMARY: 1.-Introduction. 2.-The beginnings and early meetings. 3.-The wartime and post war years. 3.1.-The war years. 3.3.-The post-war period. 4.- Holidays, sports and leisure. 5.-Respirator-dependent people. 6.-Employment and financial support for disabled people. 7.-Branches. 8.-The Bulletin and other records. 9.-Post-polio syndrome. The late effects of polio and the Fellowship. 10.-Conclusions.

ABSTRACT: The organizations set up to cope with polio in the years of epidemic outbreaks in Europe constitute an interesting focus in historiography as an example of contemporary patients' associations and mutual aid groups. The main aim of this paper is to reconstruct and analyse the principal highlights in the birth and development of the British Polio Fellowship (BPF) and its historical meaning in the history of polio associationism. The Infantile Paralysis Fellowship (now BPF) was founded in 1939 and, since then, has played an important role in the development of services for disabled people. It was founded as an organization of disabled people, not an organization for disabled people and so has always been an authentic voice of polio-disabled people. Achievements during the past seventy years have included the development of employment for disabled people, improvements in financial benefits, provision of better access, provision of holidays, the creation of opportunities for respirator-dependent people to live in their own homes, and the development of disability sport.

KEY WORDS: British Polio Fellowship, Infantile Paralysis Fellowship, disability, Great Britain, 20th century.

PALABRAS CLAVE: Asociación británica contra la polio, Asociación contra la parálisis infantil, discapacidad, Gran Bretaña, siglo XX. 


\section{Introduction}

The British Polio Fellowship ${ }^{1}$ was founded in January 1939 originally as the "Infantile Paralysis Fellowship ${ }^{2}$; this original name for the organization reflecting the medical name used to define this pathological condition at the time. The prime aims of the new Fellowship were to bring together people who had been disabled by polio, their families, friends, and supporters, and to do all that was possible to assist people in improving their lives in the face of their disability ${ }^{3}$.

The historical context in which we analyse this institution is twofold: the history of physical disabilities and the history of patient associations in the fields of health and disease. From the multidisciplinary subject of Disability Studies studies have been made, from a historical perspective, of the changes produced throughout the twentieth century; both external circumstances which involve the world of disability and the social perception of the problem ${ }^{4}$. In Britain, we have the excellent works of A. Borsay which are an essential reference and offer a broad overview, not only of the treatment of disabled people but also of the history of welfare and social rights in the country ${ }^{5}$. The situation for disabled people in Britain in the first half of the twentieth century was not good. Many factors conspired to place disabled people at a disadvantage and to inhibit positive factors in their lives. For

1. BPF from now on.

2. IPF from now on.

3. North, Barry. «Something to lean on». The first sixty years of the British Polio Fellowship. Middlesex: British Polio Fellowship; 999.

4. Disability studies are an area of growing interest in the academic field. From the point of view of historical works, many combine history, social policy and activism, such as the case of the pioneering: Barnes, Colin. A legacy of oppression. A history of disability in western culture. In: Barton, Len, Oliver, Mike. Disability studies: past, present and future. Leeds: The Disability Press; 1997, p. 4-24. Other studies of interest are: Linton, Simi. Claiming disability: knowledge and identity. New York: New York U.P.; 1998. Sticker, Henri-Jacques. A history of disability. Ann Arbor: The University of Michigan Press; 2000. Longmore, Paul; Goldberger, David. Political movements of people with disabilities: The League of the Physically Handicapped, 1945-1948. Disability Studies Quarterly. 1997; 17 (2): 94-98. Snyder, Sharon L.; Mitchell, David T. Cultural locations of disability. Chicago-London: The University of Chicago Press; 2006.

5. Borsay, Ann. Disability and social policy in Britain since 1750: a history of exclusion. Basingstoke: Palgrave; 2003. Borsay, Anne. History, power and identity. In: Barnes, Colin; Oliver, Mike; Barton, Len. Disability studies today. Cambridge: Polity Press; 2008. Kowalsky, Meaghan. Reviews in history. Available in http://www.history.ac.uk/reviews/review/453 [cited 4 Oct 2011]. Shakespeare, Tom. Disability rights and wrongs. London: Routledge; 2006. 
people with a physical disability that limited their mobility, as is the case for most polio-disabled people, the nature of the built environment was challenging, if not hostile. There were very few places or buildings which were accessible to those who used wheelchairs or who walked with crutches, stairways were the norm, public transport did not cater for disabled people, and cars which could be driven by disabled people were almost unknown.

A bigger factor than the built environment was, though, the attitudes of people towards disability, which were negative to say the least. They ranged from overt prejudice to pity or ignorance. According to historians there are two ways to explain this: the first suggests that cultural perceptions of impairments are rooted in deep psychological fears of the abnormal and unknown. The second explains these negative attitudes in terms of economic considerations that come from the Industrial Revolution as disabled people were considered unable to contribute to the «economic good of the community» ${ }^{6}$. Indeed, in Britain, social policies created discrimination and exclusion from the full rights of citizens because disabled people were seen as marginal to the labour market. On the other hand, a series of ideas and issues such as Darwinism and Eugenics ${ }^{7}$ also had an important influence in this kind of cliché on the disabled people.

From the so-called «social model» of disability ${ }^{8}$ analyses have been made of how the economic, political, and cultural barriers were, in the past, the major cause of disabled people's disadvantages. Society's response to impairment has created disability through environmental barriers ${ }^{9}$.

Concerning the history of patients' associations, studies show that they were part of a large movement that is manifested in the proliferation of mutual aid groups and growing user demand for more active participation in designing services for disabled people ${ }^{10}$. Its contemporary starting point is the mid-twentieth century, although we can find previous examples of

\footnotetext{
6. Barnes; Colin, n. 4. Finkelstein, Victor. Attitudes and disabled people. Issues for discussion. New York: World Rehabilitation Fund, Inc; 1980.

7. Borsay, 2004, n. 5 .

8. A recent review of this approach is: Martínez Pérez, José. La poliomielitis como modelo para el estudio de la enfermedad en perspectiva histórica. Asclepio 2009; 61 (1): 7-22.

9. A critical analysis on the social model applied to the British case in Shakespeare, n. 5.

10. Rabeharisoa $V_{\text {.; }}$ Callon, M. La participación de las asociaciones de pacientes en la investigación. Revista Internacional de Ciencias Sociales [article in Internet], 2002. Available in: http://www. oei.es/salactsi/volona.pdf [cited 18 Dec 2011].
} 
a process in Britain ${ }^{11}$ and in other countries. Associationism can be seen as one of the means used by civil society to develop groups for specific purposes ${ }^{12}$. The fact that in some cases, such as polio, many of those affected were children, meant that parents became very involved and chose to associate in order to deal with a problem against which medicine had no effective treatment.

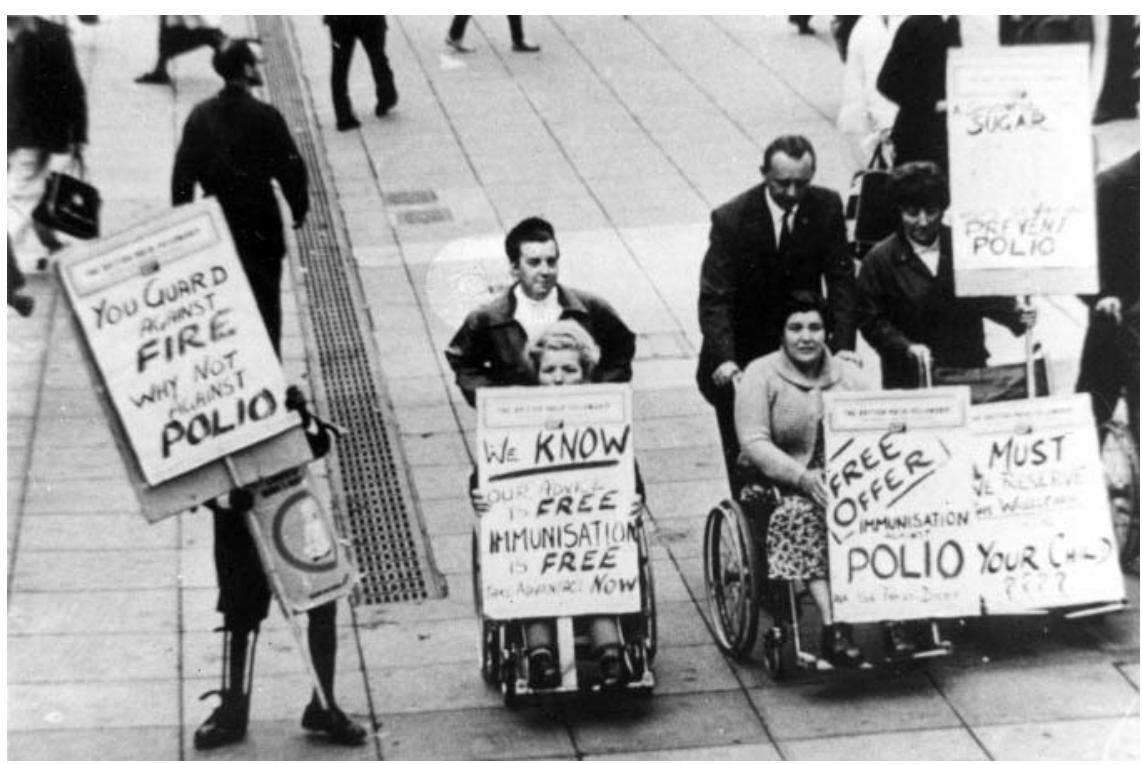

Figure 1. Public demonstration supporting vaccination against polio. British Polio Fellowship, Birmingham's branch. Source: British Polio Fellowship Archive.

A very interesting topic involves the relations between members of these associations and experts (clinicians, researchers). Rabehasiora and Callon ${ }^{13}$ have identified three types of patient associations according to the relationship with these experts. First, «auxiliary association», in which the

11. Borsay, Anne; Shapely, Peter. Medicine, charity and mutual aid. The consumption of health and welfare in Britain, c. 1550-1950. Aldersholt: Ashgate; 2007.

12. Lock, Stephen. Self-groups: the fourth state in medicine? British Medical Journal. 1986; 293: 1596-1600.

13. Rabeharisoa, Vololona; Callon, Michel. Le pouvoir des malades, L'Association française contre les myopathies et la recherche. Paris: Les Presses de l'École des Mines; 1999. 
doctor decides the most appropriate treatment, gives a degree of information to patients and expects that they (the patients) cooperate but without any active participation. In the second type, rather than simply refer to specialists, the patients, involved within an association seek the means to provide themselves with skills and knowledge to discuss the issues with experts. This second type is mainly the result of the activism developed by certain associations which, given the seriousness of the problem and the experts' lack of confidence, decide to share information and become «lay-experts». Finally, the third model is the «association of partnership». At the heart of the commitment of the patient associations' prototypical profile, the patient is considered essential for decision-making as an «expert in experience». This requires a search for procedures to collect these experiences systematically, integrate them into the scientific body of knowledge, and thereby develop the best clinical and rehabilitation practices ${ }^{14}$.

The appearance of post-polio syndrome from the 1980s onwards has been, perhaps, the most important factor behind the high number of polio associations today (nearly 400 in Europe, USA and Canada according to some recent studies $)^{15}$.

The main aim of this paper is to reconstruct and analyse the principal highlights in the birth and development of BPF and its historical meaning in the history of polio associationism. The primary sources are from the historical archive of the BPF which include several kinds of documents related to the institution such as manuscripts, photographs, tapes, printed material, films, annual reports and the Bulletin of the organization.

\section{The beginnings and early meetings}

The dimension of polio epidemics in England and Wales has recently been studied by Smallman-Raynor and his collaborators in their important monograph on the world geography of polio ${ }^{16}$. According to their analysis,

\footnotetext{
14. Rabeharisoa; Callon, n. 13.

15. Ballester, Rosa; Bueno, Eduardo; Sanz-Valero, Javier. Información, auto ayuda y creación de identidades. Las tecnologías de la información y la comunicación (TIC) y las asociaciones de discapacitados físicos. El ejemplo de la poliomielitis. Salud Colectiva. 2011 ; 7 (Supl. 1): 39-47.

16. Smallman-Raynor, Mathew; Cliff, Andrew, eds. Poliomyelitis. Emergence to erradication. Oxford: Oxford University Press; 2006.
} 
although a series of localized outbreaks were recorded in these countries during the inter-war years, the most important epidemic activity was in the early post-war period. The 1947 epidemic marked a new phase in the magnitude and diffusion of the disease (7,655 civilian and 735 military cases were reported) ${ }^{17}$ and, in fact, polio had, by the 1950 s, become a major public health problem in England and Wales. Several factors are given to explain this situation: climatic features (eg. the unusually dry summer of 1947), poor nutrition and rationing in the early post-war period, and the possibility of importation of a new and virulent strain of poliovirus with returning troops ${ }^{18}$.

The situation in other countries was no better. In the case of the USA, there was a series of outbreaks and one of them, in 1954 (57,628 cases reported: 3,145 deaths and 21,269 with mild to disabling paralysis), is considered the worst outbreak in the nation's history and is credited with heightening parents' fears of the disease and focusing public awareness on the need for a vaccine ${ }^{19}$.

However, other similar situations had very different social responses. Thereby, as Tony Gould ${ }^{20}$ suggests, there was no pressure group in England and Wales comparable to the US National Foundation of Infantile Paralysis, a very powerful and entirely new kind of voluntary organization, founded by the President of the United States that spent large sums of money on several initiatives that, included economic support for research ${ }^{21}$. The British Polio Fellowship was a completely different kind of group, a social organization - as befits the word fellowship - intent on self-help and mutual support, as commented William Bradley, delegate for England and Wales at the First International Conference on polio ${ }^{22}$. It was ahead of its time

\footnotetext{
17. Smallmann-Raynor, n. 16, p. 335-346.

18. Smallmann-Raynor, n. 16, p. 246.

19. Rogers, Naomi. Dirt and disease. Polio before FDR. New Brunswick: Rutgers University Press; 1992. Oshinsky, David. Polio. An American story. Oxford: Oxford University Press; 2005; Wilson, Daniel. Living with polio. The epidemic and its survivors. Chicago-London: The University of Chicago Press; 2005. Wilson, Daniel. Silent voices: An oral history from the American polio epidemics and worldwide eradication efforts. Westport: Praeger Publishers; 2007.

20. Gould, Tony. A summer plague. Polio and its survivors. New Haven and London: Yale University Press; 1995, p. 14.

21. Oshinsky, n. 19.

22. Bradley, William $\mathrm{H}$. The importance of poliomyelitis as a world problem. In: Poliomyelitis. papers and discussions presented at the first international poliomyelitis conference. Philadelphia: J. B. Lippincott 1949, p. 54.
} 
in the sense that it was an organization run by disabled people themselves and an authentic pioneer.

The birth of the British organization is clearly associated with two important figures that played a fundamental role in setting up the BPF: Patricia Carey and Frederic Morena. Patricia Carey was aware of negative attitudes towards disabled people. She returned to England from India where she had contracted polio as an eight-year-old in the 1920s. Patricia was not particularly badly disabled by the disease but was frail and walked with a stick. She was intelligent, educated, and came from a good background, nevertheless Patricia found life as a disabled person to be difficult. Her points of view on social attitudes towards disabled people are reflected in many sources and by oral witnesses ${ }^{23}$. Many of the approaches and attitudes that Patricia saw in society appalled her; she could not understand why people were so insensitive. Yet Patricia saw something very different in the disabled people with whom she met; here she saw a quiet determination to get on with life, a high level of personal dignity - quite the opposite to that which was usual in society- a very real interest in living life to the full.

From her personal vision of how to overcome this situation, Patricia did not find the solution in organizations already established. In the 1930s there were organizations for disabled people in England. The important word here, though, is «for»-organizations in which concerned able-bodied people would make efforts to better the lot of those whom they saw as lesser or perhaps, even, second-class. Many city and county areas in Britain would have some form of Committee for the Care of Cripples ${ }^{24}$ which, in the days before the welfare state would help to provide callipers, crutches, and the crude canvas-seated wheelchairs which were common at the time. However, the recipients of this limited largesse were rarely allowed to be members of the bodies which made the decisions.

Some self-help groups had been formed in Britain, none of which Carey is likely to have known about. In 1938 three disabled men in Coventry,

23. The Oral History Heritage Project shares recorded and saved spoken experiences of fifty members of the BPF. The interviews and audio recordings were conducted on behalf of the BPF by Heritage Project workers following training with the Oral History Society. The records are available at: http://www.heritage-britishpolio.org.uk/heritage-project [cited 15 Dec 2011].

24. Girdlestone, Gathorne Robert. The care and cure of crippled children. Bristol: J. Wright; 1924 (Reprint: Arno Press; 1980). 
England, formed The Coventry City Cripples Club which survived for many years eventually becoming the Enterprise Club for Disabled People. Across the Atlantic in New York City in 1935 the League of the Physically Handicapped ${ }^{25}$ had been formed to protest against the direct discrimination against disabled people in the allocation of employment. In Norway as far back as the early 1920s the Norwegian Association of Disabled People had been formed ${ }^{26}$.

Patricia Carey knew that something needed to be done but she had no idea about how to go about it. Another important priority in her life was self-improvement and she wanted to be able to work for her living and take a useful place in society. She decided to improve her knowledge of German and French and so, through a mutual physiotherapist, was introduced to a language teacher, also disabled by polio, Frederic Morena. He had been a moderately well-known actor specializing in classical roles and a member of the Old Vic Company until he contracted polio at the age of 42. As Frederic was now a full-time wheelchair user his acting career was, effectively, at an end. However, Frederic was a linguist and so took to teaching French and German, two languages in which he was fluent. It was this resource which led to him meeting Patricia Carey. It is thought that the two of them did little teaching or language learning for, quite quickly, Patricia saw in Frederic a man who had refused to be beaten by his disability despite its very late onset in his life and the profound effect that polio had created on his career.

At the end of the 1930s, Carey and Morena were both aware that many disabled people, mainly the polio-disabled for whom they had a very particular personal concern, were capable of much more in life than social attitudes would allow, that polio-disabled people could contribute usefully to society, that hiding people and denying them opportunities was wrong.

Patricia Carey therefore proposed that a new organization be formed of disabled people to create situations in which there could be mutual support and personal development. At first Morena rejected the notion,

25. Longmore, Paul; Goldberger, David. The League of the Physically Handicapped and the Great Depression: A case study in the new disability history. Journal of American History. 2000; 87 (3): 288-322. Available at: http://www.historycooperative.org/journals/jah/87.3/longmore. html [cited 15 Nov 2011].

26. Note, in both these examples of activity outside Britain the organization's name included the word «of» rather than «for» which was more common in the UK. 
perhaps because he had been influenced in some way by the change in his own personal circumstances over recent years. Indeed, he had spent most of his life as an acclaimed actor, entertaining people and often holding centre stage. As a cripple in a wheelchair ${ }^{27}$ he was now subjected to the struggles and privations of disablement. However Carey was not to be

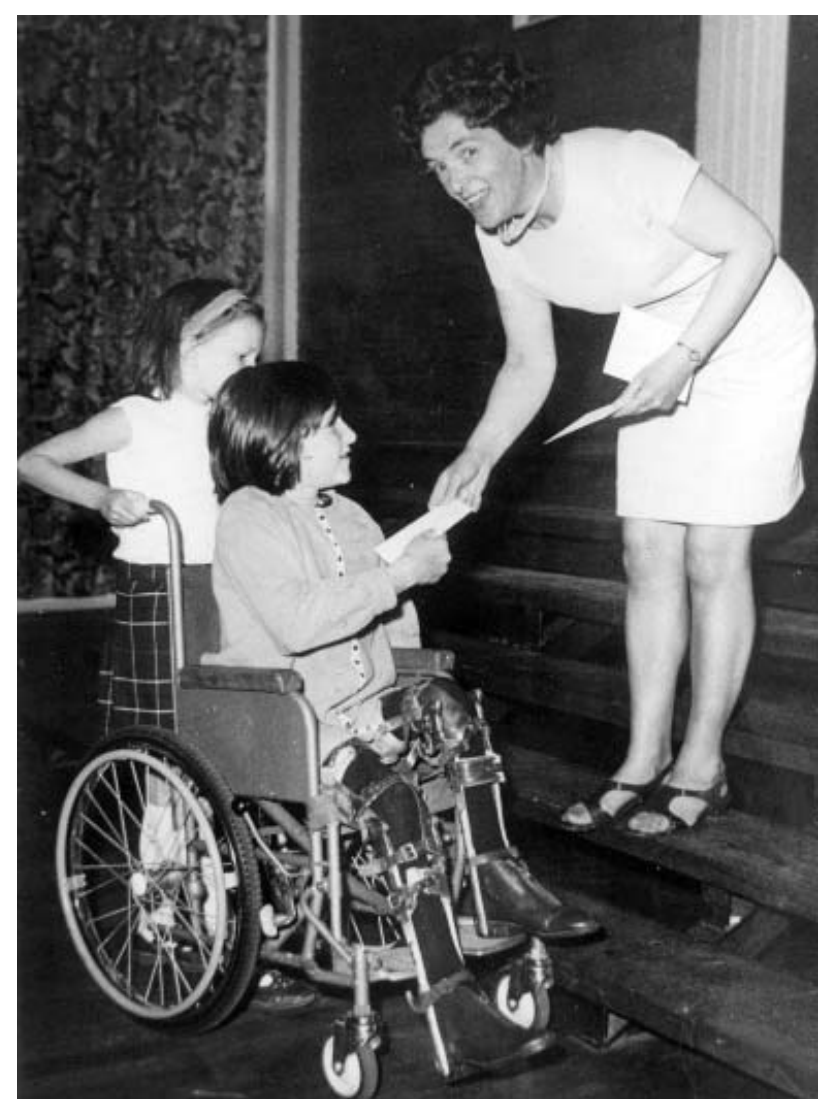

Figure 2. A little girl from BPF receiving a prize. Source: British Polio Fellowship Archive.

27. Wilson, Daniel. Living with polio. The epidemic and its survivors. Chicago: The University of Chicago Press; 2005; Wilson, Daniel. Braces, wheelchairs and iron lungs: the paralyzed body and the machinery of rehabilitation in the polio epidemics. Journal of Medical Humanities. 2005; 26 (2-3): 173-190. Both papers are very interesting reflections on changes experimented in the ordinary life of disabled people by the use of these types of devices. 
discouraged; she had an energy and determination that far outclassed her frail physical state. She continued to argue her case until, after a number of weeks, Morena finally succumbed and agreed to help Carey form an organization of people who were disabled by Infantile Paralysis (as polio was known at that time).

The early conversations between the two founders of the organization took place at the end of 1938 and, from the time that Morena gave his agreement, they both worked tirelessly on arranging an inaugural meeting. Both were in contact with polio-disabled people and notices were sent out inviting people to an exploratory meeting to be held in a small private art gallery in Nassau Street, Bloomsbury, in London, on 29th January 1939.

Approximately thirty people attended the first meeting and unanimously supported the idea of a new organization ${ }^{28}$. There was also a consensus that this was to be an organization of polio-disabled people not an organization for them. The organization was to provide support, development, and mutual encouragement. It was to be a fellowship of people living with the effects of Infantile Paralysis, including families and friends. Thus emerged the name for the new organization: The Infantile Paralysis Fellowship. Waldo Eager was appointed chairman and Frederic Morena became secretary.

Having set up an organization, it now became necessary to create something that would deliver the objectives of the founders. The new Fellowship began its activities with its own funds of approximately $£ 5.00$ which, even in 1939, was scarcely enough. Both Carey and Morena had contacts and were able to utilise their friendships to give more publicity to the fledgling Fellowship. Further meetings were held. Following a letter from Hugh Fletcher Moulton in The Times ${ }^{29}$ some sixty people came to the Lyons Corner House restaurant in The Strand, London, for a second meeting. Another meeting was arranged for May 1939; two hundred people were expected, four hundred arrived and Carey's vision had been corroborated.

From the outset it was obvious that meetings in central London would not be enough and thus the Fellowship decided to publish a regular news bulletin in order to keep in touch with its members throughout Britain. Dudley Chapman ${ }^{30}$, himself polio-disabled, had a small printing business at the time and offered to produce the first newsletter; a simple one-sheet

\footnotetext{
28. British Polio Fellowship. Annual Report, 1979. Gould, n. 20, p. 165.

29. North, n. 3, p. 3.

30. North, Barry. Polio personalities. Dudley Chapman. In: North, n. 3, p. 14-15.
} 
publication that bore the name The Bulletin - a title which has remained for over seventy years ${ }^{31}$. Although polio research was not among the objectives of the IPF, the pages of The Bulletin echoed some articles dealing with the issue, especially due to the influence of Duncan Guthrie, a layman appointed director of the research campaign of the organization in $1952^{32}$. He gave the go-ahead to establish a fund for research. «The Research fund will be the child of the IPF and the IPF will, before very long, have good reason to be a very proud parent» ${ }^{33}$ but, later he set up an independent Polio Research Fund ${ }^{34}$.

\section{The wartime and post war years}

\subsection{The war years}

The declaration of war on Nazi Germany in 1939 brought a dramatic change in the regular life of the population in Britain. The influence of war on the morbidity and mortality by polio in England, Scotland and Wales, has been studied specially in terms of the results of the evacuation of schoolchildren and others from urban areas during the two periods of evacuation (193940 and 1944-45) and the possibility that the number of cases of infectious diseases would increase. The hypothesis was that children from crowded cities were carrying this kind of pathology — polio among them - into rural districts. The important studies by Smallmann-Raynor and his collaborators have been fundamental in clarifying this issue ${ }^{35}$.

The difficulties caused by the war had an impact, in a more marked way, among the most vulnerable people in the population, including people with physical disabilities. It was difficult, even dangerous, to travel and many everyday items were in very short supply. Many members of the Fellowship were unable to put on a uniform and see active service. Indeed the challenges

31. Together with The Bulletin, and almost from the outset some monographs were published such as: Arlott, John. The problem of infantile paralysis. London: The Infantile Paralysis Fellowship (undated).

32. Guthrie, Duncan. The energetic pursuit of research. IPF Bulletin. 1952; issue 130.

33. Gould, n. 20, p. 169.

34. Gould, n. 20, p.169-70.

35. Smallman-Raynor, Mathew. Wartime evacuation and poliomyelitis in Southeast England. In: Smallman- Raynor, n. 16, p. 324-335. 
and difficulties that the citizens of Britain faced were increased by their disability but the spirit of the Fellowship was not to be daunted and its activities were resumed again in post-War times.

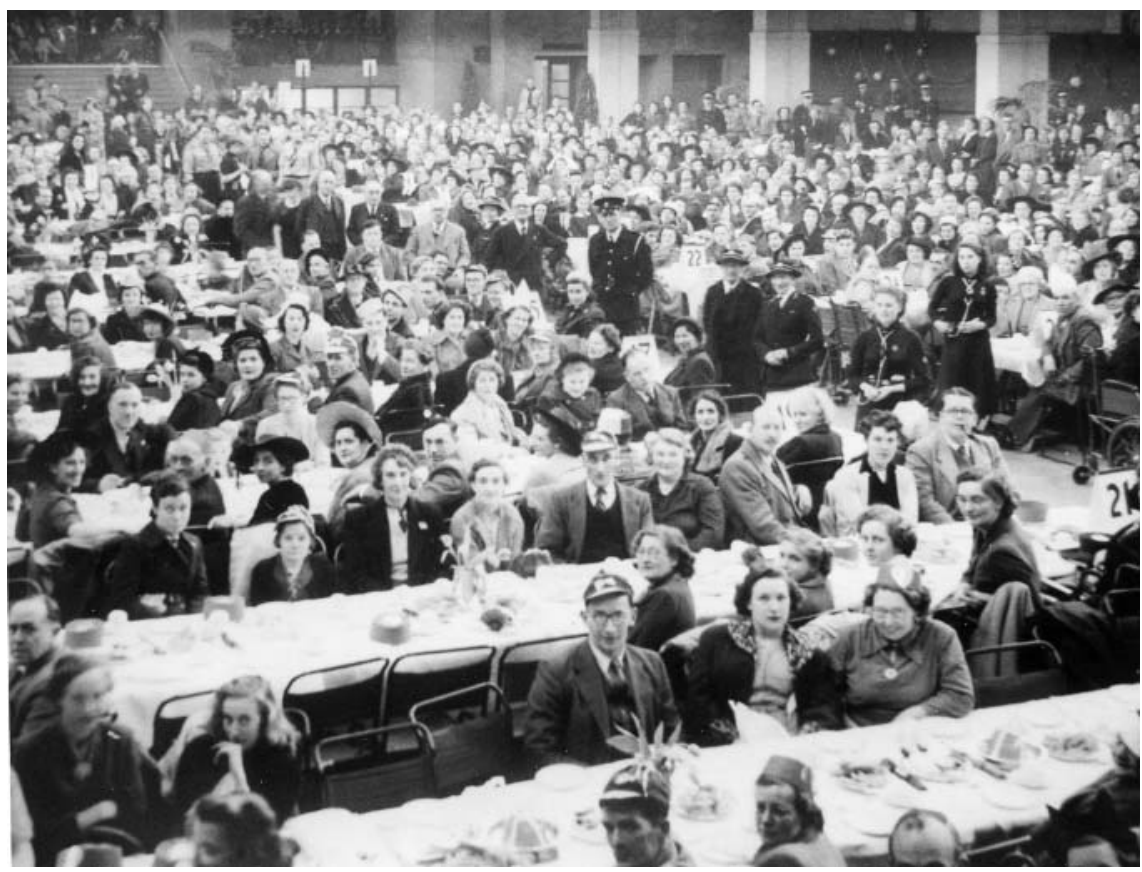

Figure 3. Celebrating Christmas at the end of the 1940s. The National Christmas Party was a tradition from the beginning of the BPF. Source: British Polio Fellowship Archive.

At the end of 1939 the Fellowship held a national Christmas Party thus starting a tradition that went on for many years. Still the number of members was increasing and Frederic Morena, working from his home, received letters from members from all over Britain. Many of these letters spoke of the frustration that polio-disabled people felt in not being able to 'do their bit' in the war effort. Most IPF members were unemployed and very few jobs were open to them. Nationally, though, there were many jobs unfilled as their previous holders had been called up to armed service. By now the Chairman of the Fellowship was Roby Spence and he took the seemingly bold step of writing a letter directly to Ernest Bevan M. P. who 
had government responsibility for employment. He suggested that while polio-disabled people may not have full physical capabilities, their intellectual powers and their determination were intact and they could undertake, perhaps with a degree of adaptation, the jobs that were left vacant ${ }^{36}$. Thus the government policy of not employing disabled people in essential war work was changed and polio-disabled people were able to play their part in

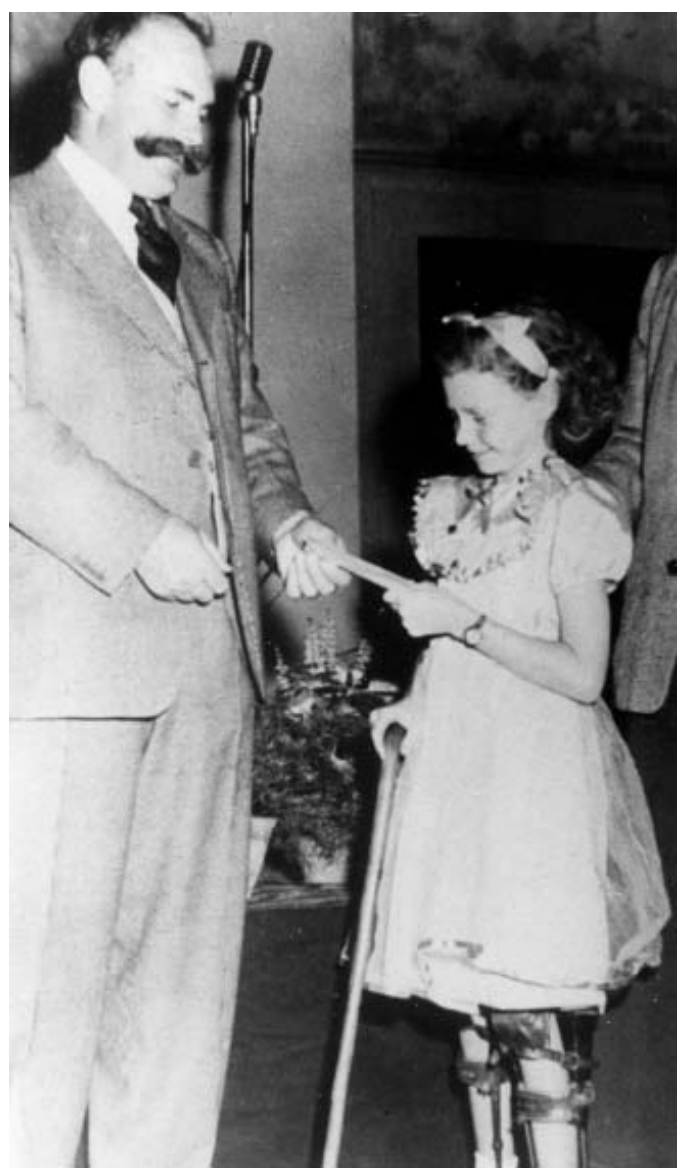

Figure 4. Young member of the BFP receiving a cheque from a celebrity supporter of the organization at a National Christmas Party. Source: British Polio Fellowship Archive. 
the war effort. This wartime development played an important part in laying the foundations for post-war employment legislation and was important in opening the door for today's equality legislation ${ }^{37}$.

As well as helping the nation the opportunity to work had a profound effect on those polio-disabled people who now had jobs. Albert Holman who had become disabled by polio as an adult before the war, wrote at the time:

«Now I am back amongst the men, the machines. Once more I sniff the odour of hot oil, hear the scraping of files on metal, sometimes I hear the coarse jokes. I hear the serious exchange of opinions of thinking men, I take part in the endless little incidents that are all part of a day's work. In fact, despite infantile paralysis, despite the wheelchair, despite all the handicaps, of a man unable to walk, I am once more one of the crowd and, with the goodwill of my employers and workmates, I hope to continue for many years to come» ${ }^{38}$.

It was for developments such as Albert Holman describes that the Fellowship was founded. To make those differences in polio-disabled people's lives that bring them back into society, to create dignity, to encourage achievement, and to reduce the effects of disability.

Despite his work commitments at the Ministry of Supply, Morena also continued his role as secretary to the Fellowship. It was possible to print The Bulletin only when Dudley Chapman was able to obtain supplies of paper but publication continued throughout the war years.

In order to survive, the Fellowship still required money and without being able to hold meetings, fund-raising became problematic. In the early 1940 s the Fellowship obtained the use of a bomb-damaged shop and started to sell second-hand items that people had donated ${ }^{39}$.

\subsection{The post-war period}

The setting up, in 1948, of the National Health Service, was a landmark in the development of health services in Britain within the framework of the

37. The case of British legislation related to the disabled in the twentieth century has been analyzed by Bynoe, Ian; Oliver, Mike; Barnes, Colin. Equal rights for disabled. The case of a new law. London: Institute for Policy Research; 1991.

38. Holman, Albert. Quoted in Arlott, John. The story of the IPF (undated). BPF Archive.

39. North, n. 3, p. 6-8. 
Welfare State ${ }^{40}$. Gould refers to a talk by William Bradley, from the British Ministry of Health at the First International Poliomyelitis Conference that was held in New York in 1948 at which he pointed to the «comprehensive provisions by various Ministries in the Government for the care of paralyzed persons, their education and absorption into industry» ${ }^{41}$ but, at the same time he considered that voluntary bodies were still required.

The Infantile Paralysis Fellowship found a new lease of life too. On the outbreak of peace the Fellowship organised a Victory Rally over the first weekend in September 1945. People attended a garden party in the grounds of Lambeth Palace, the home of the Archbishop of Canterbury, and in the evening went to the theatre. The next day there was a tour of London, lunch in a restaurant and a time of fellowship until tea ${ }^{42}$.

However, much was to be done in the immediate post-war years if the Fellowship were to survive and succeed. Simply remaining in existence during the war had created a positive impression; the growth in numbers during that time and the successes that had been achieved meant that the Fellowship was building a reputation as the authoritative voice of poliodisabled people. And, of course, this voice was not confined to just one disability; the Fellowship, in many ways, spoke on behalf of all disabled people.

As the Fellowship became larger and developed into a national organization it became necessary to create a formal structure of governance. A Declaration of Trust was adopted on 8th March 1947 which was amended over the following six years until a new Trust Deed was adopted on 17th April 1953 which, essentially, remains in force today. The 1953 Trust Deed appointed four trustees one of whom, Joe Fisher, is still active with the Fellowship today and was the founder of the Newcastle employment project. The Trust Deed established rules which enabled branches to be set up under the guidance of the Central Office as well as regional sections; these sub-groups were able to raise and spend their own funds in support of the objectives of the Fellowship. The overall national management of the Fellowship remains in the hands of an elected committee of trustees;

40. A critical analysis on the importance and social and political meaning of the NHS and how it is presented in historiography is: Gorsky, Martin. The British National Health Service 1948-2008: a review of historiography. Social History of Medicine. 2008; 21 (3): 437-460.

41. Gould, n. 20, p. 161.

42. North, n. 3, p. 11. 
the system of election of trustees was amended in 2009 to offer a more equitable system of appointment.

Some of the changes that the Fellowship sought to bring about were profound, others were simple. Many involved changes in attitudes, some required changes in the law. One of the most popular forms of entertainment in the post-war years was the cinema but legislation made it almost impossible for a wheelchair-user to «go to the pictures». In order to create a safe environment in case of emergency, the law required that the audience sit on fixed seats, there were no spaces for wheelchairs and if a wheelchair-user were to transfer to a fixed seat, they could become a hazard as they would be unable to evacuate the cinema.

Frederic Morena knew the cinema well -indeed he had appeared in a number of films - and he knew the frustrations of not being able to see films in public. In an attempt to change the regulations, Frederic asked Michael Flanders, a young polio-disabled man, to organize a campaign to make cinemas wheelchair accessible. Flanders was a singer who performed on stage despite using a wheelchair and, later in life, was to find fame with Donald Swann in a popular duo. Flanders was energetic in his campaigning to get wheelchair-users into cinemas and, after a few years, the law was changed ${ }^{43}$.

\section{Holidays, sports and leisure}

Going to the cinema and having a job were two aspects of life that had been opened up to disabled people through the efforts of the Fellowship but another crucial part of life was still a source of great difficulty - that of going on holiday. In the mid-1940s many hotels and holiday venues had no facilities at all for people who used wheelchairs and other disability equipment. Many hotels did not even have lifts and, often, management attitudes to disabled people were unwelcoming, if not hostile. Members of the Fellowship were well aware of this situation and, during the war years of forced inactivity, determined that, when peace came, one of the first things that the Fellowship would do would be to arrange for polio-disabled people to be able to take holidays.

43. Polio. A living history. Available at: http://www.Heritage-britishpolio.org.uk the decades [cited 5 January 2012]. 
The John Groom's organization for disabled people ${ }^{44}$ owned a residential home on the coast at Clacton in Essex and, in 1945, it was announced that the Fellowship was to acquire this establishment and open it as a holiday hotel. However, in 1946 this plan failed and no evidence for the change of plan appears to be recorded. The Clacton hotel may no longer have been a reality but the need and desire for a holiday hotel remained.

It was not until 1950 that the plan for a hotel came to fruition. The trustees of the Fellowship discovered a hotel for sale in Worthing in Sussex and decided that it would be ideal for their plan. Shelley Road, where the

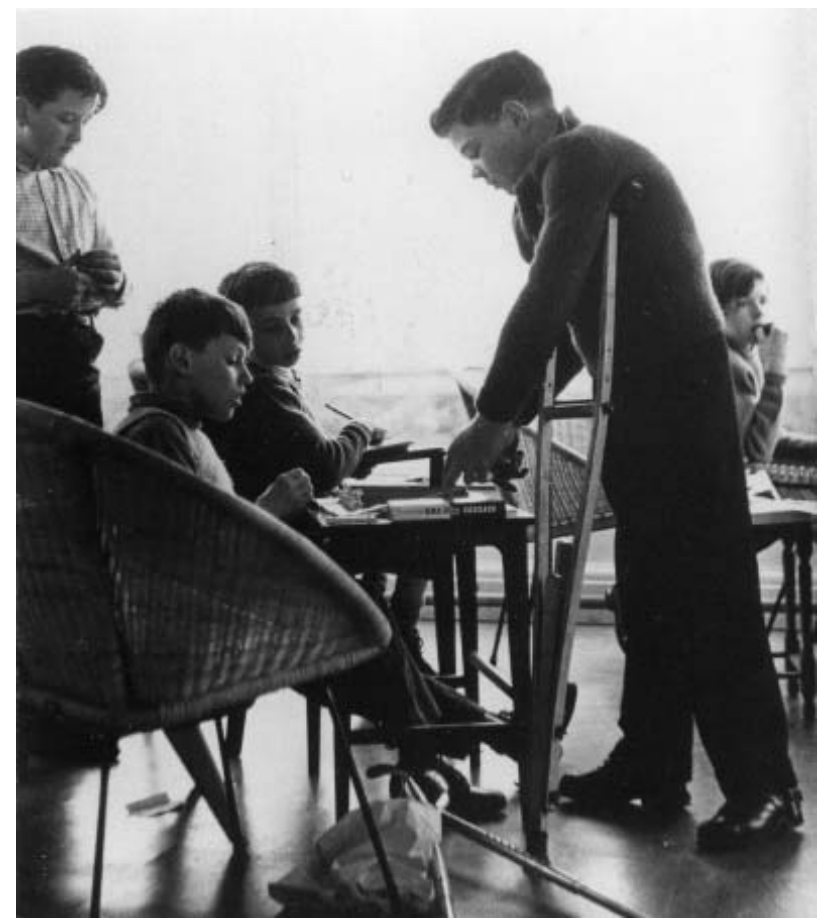

Figure 5. Young members of the BPF on holiday at the Nothern Lantern Hotel (Worthing, Sussex), acquired by the association ca. 1950. Source: British Polio Fellowship Archive.

44. John Alfred Groom was a London engraver and evangelical preacher who became concerned with the work of charities, including the problems caused by disability. He expanded his previous work on deprived and orphan children, with housing for the disabled during the early 1970s. Records of John Groom's Association for disabled people and predecessor organizations are shared in the London Metropolitan Archives. GB 0074 LMA/4/4305. 
hotel was located is a short distance from the sea front, Worthing is a town that has no steep hills and so was ideal for people with limited mobility, the hotel was close to the town centre and had closed at the end of the 1949 season and been put up for sale. The Fellowship purchased the hotel ${ }^{45}$.

The fact that the Fellowship had a very limited amount of money in the Holiday Home Fund and could not really afford the purchase appeared to be of no consequence. So sure were the trustees that the hotel was the correct thing to do that they took an act of faith and bought the property. In fact, the hotel opened for business to Fellowship members at the very first opportunity in 1950 - the Easter weekend of that year which signalled the beginning of the summer season. The original hotel was not adapted in any way for disabled people and, for those first few months of Fellowship operation nothing changed - facilities such as a lift, enlarged bathrooms, handrails, hoists, etc. would come later. In fact, the Fellowship's archive has a photograph of a lady with callipers on both legs struggling up the stairs at the hotel on the very first weekend of operation.

For now, the important thing was to be able to offer Fellowship members a place for their holidays (and probably to make some money too). Having bought the hotel, the Fellowship needed a name for it and so a competition to find a name was organized through The Bulletin in February $1950^{46}$. The article in the newsletter then announced the purchase, the opening date, and the naming competition. It described the hotel telling readers that when it closed, the hotel was known as The Lantern. Many interesting names were suggested but one person asked why there should be a change: The Lantern seemed a perfectly good name for the hotel as it reflected the positive approach of the Fellowship and would surely bring light into the lives of many polio-disabled people.

The Lantern was formally opened by Air Chief Marshall Sir John Slessor on 5th April 1950. Improvements were made over the next few years and a number of extensions were added to the hotel in later years. The additional capacity meant that The Lantern was able to offer permanent accommodation to some people and so a dual use was adopted: the hotel became partly a holiday venue and partly a home for polio-disabled people.

\footnotetext{
45. North, n. 3, p. 59-66.

46. The Bulletin, Infantile Paralysis Fellowship, London, February 1950 (BPF Archive).
} 
It is a fact of life that, during the seventy years of the Fellowship, attitudes to and opportunities for disabled people have changed greatly. This, after all, is what the Fellowship set out to do back in 1939. One aspect of the success of those changes is that disabled people, along with everyone else, have very different expectations of a holiday. No longer are people content with a week by the sea on the south coast, people want and can obtain a holiday in the sun, to fly to an adventure, and disabled people are not left out of these desires for a different type of holiday. So, it may be said that The Lantern became a victim of the Fellowship's success; people did not want to go to Worthing for a holiday by the early twenty-first century and the complexity and costs of running a residential home for disabled people were placing the Fellowship's funds under strain. Thus, The Lantern closed in 2005.

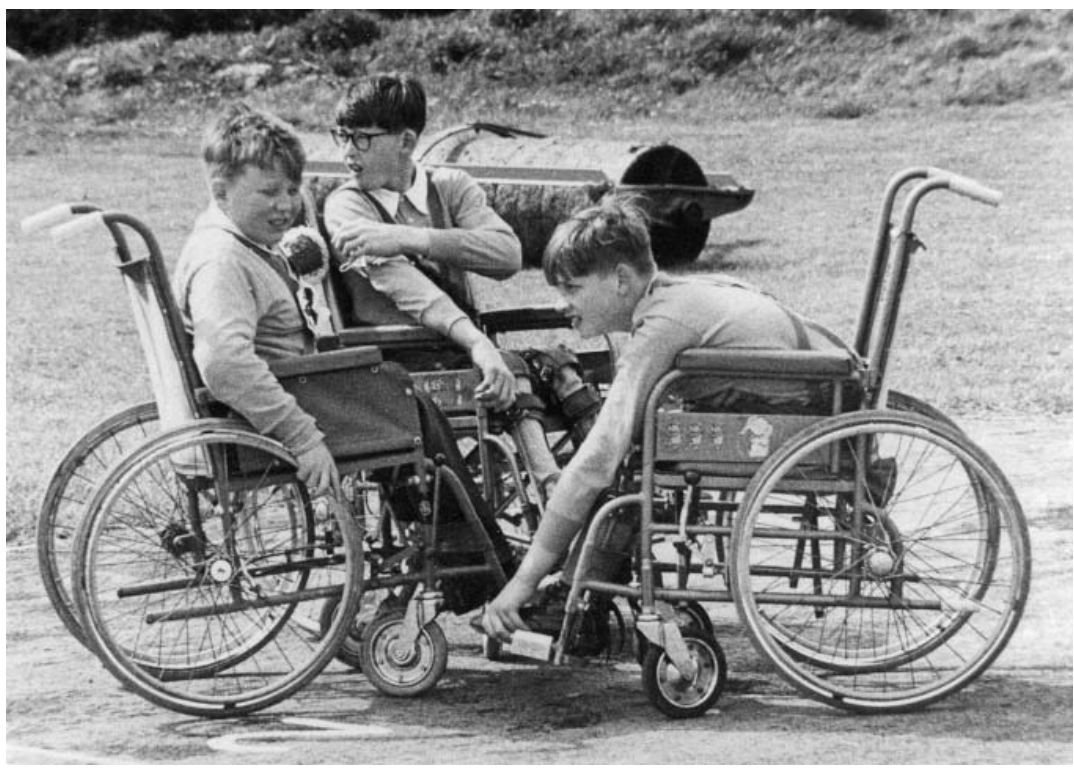

Figure 6. Competition at Stoke Mandeville Sports Stadium. Source: British Polio Fellowship Archive.

Right from the start, one of the problems of The Lantern in Worthing was its location, it was right on the south coast of England. In the early days before a proper motorway system in Britain, when disabled people generally had small three-wheeled cars, and when wheelchair-users had to travel in 
the luggage compartments of trains, the south coast was very difficult to reach if one lived anywhere north of the Midlands. It soon became apparent that one hotel would not be enough. Accordingly, in 1955, a large house in Lytham St. Anne's, Lancashire was purchased and converted into The Northern Lantern. This venture did not transpire to be as enduring at its south-coast sister and the Northern Lantern was closed in 1977.

As well as the main hotels, the Fellowship and its branches have owned a number of single-storey houses and caravans that have been adapted for the use of disabled people; some of these are still in use for holidays.

In the late 1940s there was great caution about allowing polio-disabled people to use public swimming pools as it was thought that they might spread the disease to other users. This is not true for once an individual has passed the acute stage of polio infection he or she is no more infectious than anyone else. However, the fear of polio being spread through water, which was common at the time, led to prohibitions on the use of public swimming facilities ${ }^{47}$.

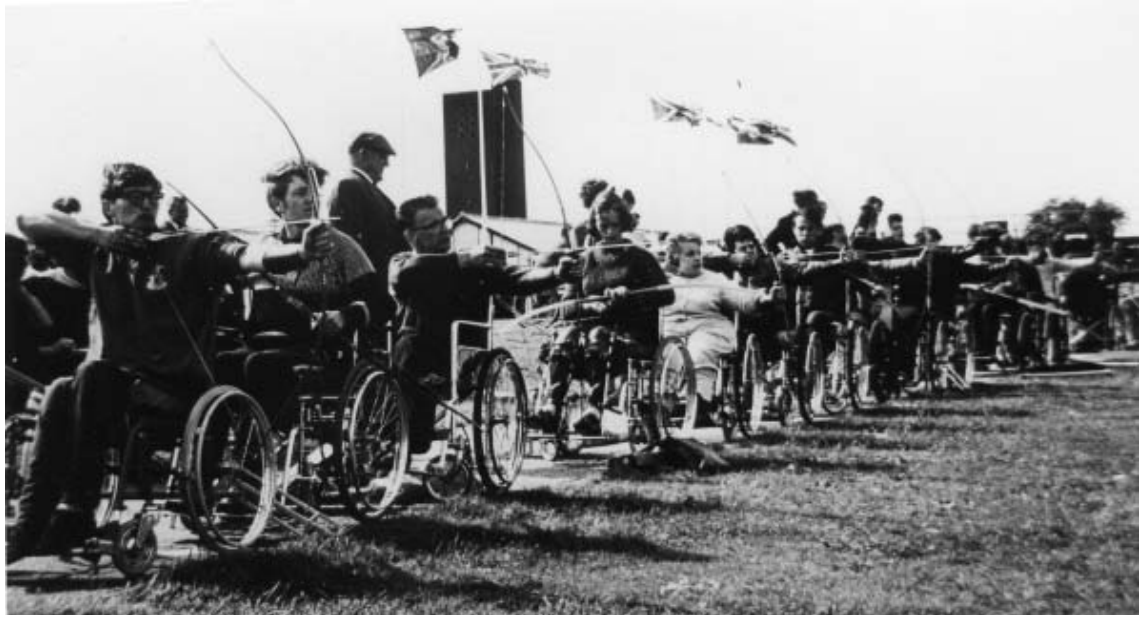

Figure 7. Archery competition amongst Fellowship members. Source: British Polio Fellowship Archive.

47. The recent novel Nemesis (Roth, Philip. Nemesis. New York: Houghton Mifflin Harcourt Pub. Co.; 2010) is an excellent example of this kind of fear in a North American community during the 1940s polio outbreaks. Otherwise, the historiography on polio has many documental and oral sources and witnesses on this same situation. 


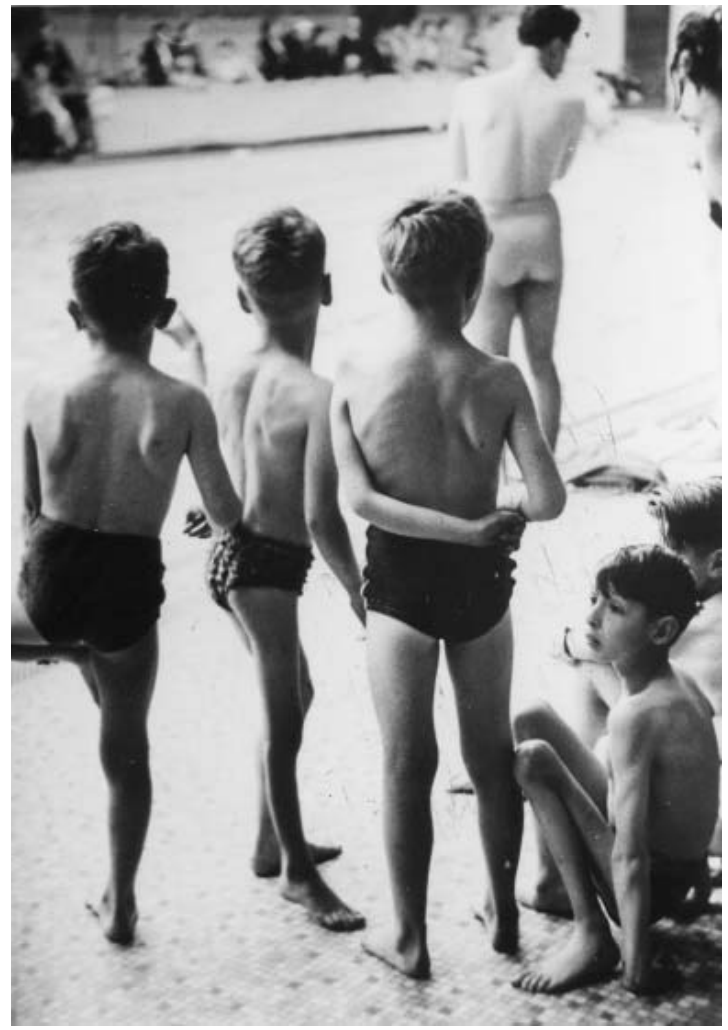

Figure 8. National Swimming Gala at Seymour Hall Baths (London, 1955). Source: British Polio Fellowship Archive.

Frederic Morena knew that polio-disabled people were safe in swimming pools and also, through hydrotherapy, knew the benefits of swimming to Fellowship members. Actually, hydrotherapy and Kinesitherapy in swimming-pools, were among the most important physical therapies used for this kind of pathology, especially both to prevent and to treat the paralytic effects of polio. Thus, in 1952, Morena spoke to the national annual meeting of swimming pool managers and, in his powerful and persuasive way, convinced them that polio-disabled people offered no risk to other pool users. Policies were quickly changed and many swimming pools made special arrangements to welcome groups of disabled people even, in some instances, increasing the temperature of the water to make the swimming experience more beneficial. 
Once polio-disabled people had started swimming the urge to race came to the fore. The Fellowship organised its first National Swimming Gala in 1955 and, from the following year, competition took place firstly at a regional level and then onwards to the national championships. The Fellowship also organized, from the 1950s, local, regional, and national competition in a range of sports including wheelchair racing and slalom, and archery ${ }^{48}$.

The Fellowship worked closely with other organizations and actively supported the pioneering work of the German neurologist Sir Ludwig Guttmann at the Stoke Mandeville Hospital in Aylesbury, Buckinghamshire. The Fellowship Games were combined with other sports in the original Stoke Mandeville Games which were the precursor of today's Paralympic Games and the world-wide disability sport movement ${ }^{49}$.

\section{Respirator-dependent people}

One of the caravans owned by the Fellowship was to be used to demonstrate some important facts for people who were the most severely disabled by polio. There have always been people whose level of disability caused by polio is such that they need to rely on mechanical breathing. In the middle of the last century such respiratory support was provided by the tank respirator, commonly known as the «iron lung» ${ }^{50}$. Furthermore, the use of the iron lung required full-time and permanent hospital care and polio patients were not able to live in their own homes.

Brian Sandiford, a doctor at the Priorsdean Hospital in Portsmouth, did not agree with current thinking about the needs of respirator users and enlisted the help of the Fellowship in an experiment. Funds were raised and the Portsmouth and Southsea branch of the Fellowship purchased two

48. Reports of sports activities are published in many editions of The Bulletin from 1952 to the present.

49. Goodmann, Susan. Spirit of Stoke Mandeville. The story of Sir Ludwig Gutmann. London: Collins; 1986.

50. On the history of the Drinker-tank respirator and its meaning within the history of medical technologies: Stanton, Jennifer. Supported lives. In: Cooter, Roger; Pickstone, John. Companion to medicine in the twentieth century. London: Routledge; 2000, p. 601-615. On personal experiences inside this device. Black, Kathryn. In the shadow of polio: a personal and social history. New York: Addison-Wesley; 1996. 
large caravans which were to be located on a commercial caravan site on the south coast of England. One of the caravans was specially-built with a strengthened floor and moveable walls that would enable it to house different types of respirator. A nurse would sleep in the caravan with the respirator user whilst other family members used the second caravan ${ }^{51}$.

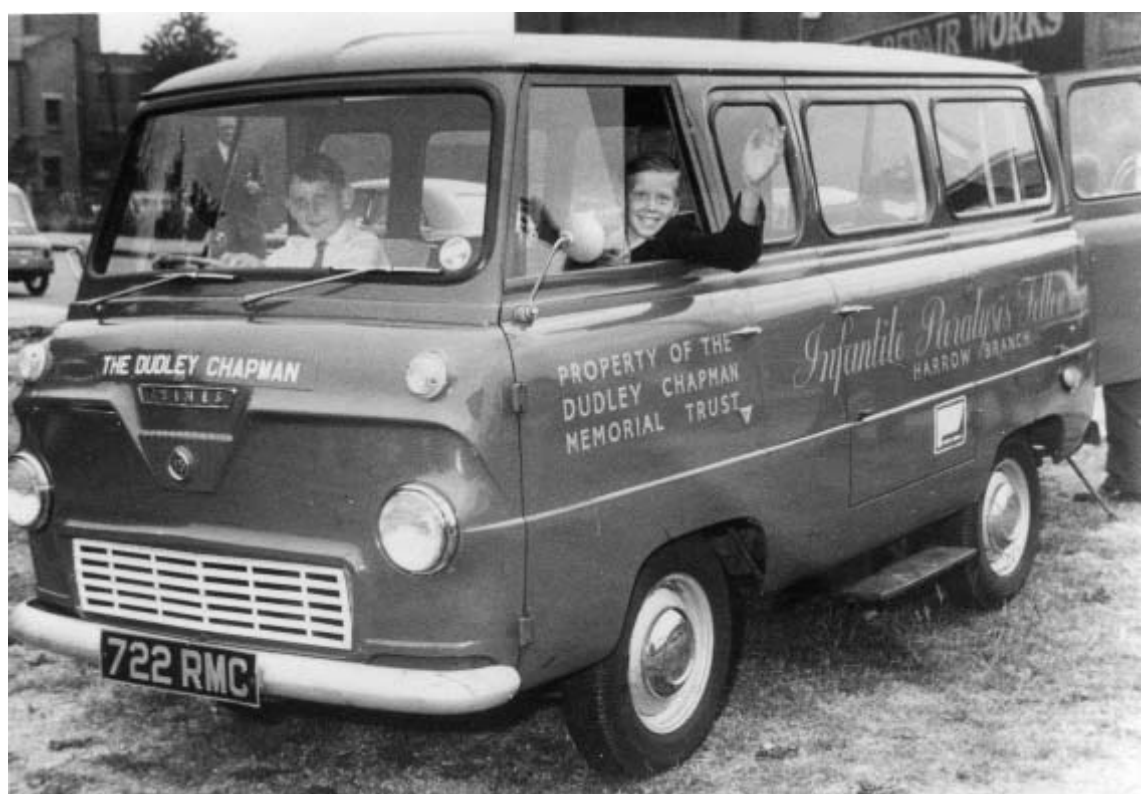

Figure 9. The «little red bus». Source: British Polio Fellowship Archive.

The caravans were in use for seven years during which time they attracted world-wide attention from medical and rehabilitation professionals. Not only were the doctors impressed, the residents liked it too as they were able to demonstrate that they could leave hospital, they could live at home, and that they could do things which, previously were thought impossible. The Portsmouth caravans were a great success and in some sense, can be seen as one of the pioneer initiatives of the current rehabilitation approaches to coping with severe paralysis. 
The instigator of perhaps the most unusual political demonstration of the 1960s was a member of the Fellowship. On 24 September 1969, Isabel Huie led twenty-nine respirator-dependent people into Downing Street in an attempt to persuade the government to change its policy on incomes for people with severe disabilities ${ }^{52}$.

\section{Employment and financial support for disabled people}

The involvement of the Fellowship in creating the opportunities for disabled people to have employment during the Second World War have already been mentioned but, sadly, the advances of the war years did not translate into universal employment opportunities for disabled people. Indeed, as Britain returned to normality following the war, employment became more difficult to obtain and as is often the case, disabled people were the last to be considered when filling vacant posts. The Fellowship recognised the need to improve the employability of disabled people and, thus, inaugurated some employment schemes of its own. A number of local branches of the Fellowship created employment projects which had varying degrees of success but the only national project was inaugurated in Newcastle in 1954. For some years the Fellowship had been selling Christmas cards in order to raise funds. The cards had been printed by Dudley Chapman at his works in West London and were made available to the Fellowship at very low prices ${ }^{53}$. After Chapman's premature death at the age of 42, it was decided to use the production and distribution of cards as a training and employment project. The Fellowship's branch in Newcastle was enthusiastic to develop this project and managed to persuade the local university Students' Union to donate all of the income from their annual fundraising activity to the project. Accordingly, the Newcastle branch received some $£ 13,000$ which enabled the purchase, in 1956, of a large house in the city, to convert it to be suitable for hostel accommodation for disabled people, and to erect buildings at the rear of the house in which the employment project would be located.

52. North, n. 6, p. 86 .

53. North, n. 3, p. 38-40. 
The thinking behind the Newcastle project was that people who were disabled by polio were capable to obtaining a job but often had difficult in demonstrating to potential employers that they had the capacity to do the work. The Newcastle project treated its employees as just that, employees. People were expected to arrive at work on time and to work efficiently to produce the goods which created the income. Employees were paid a proper wage and they paid rent for their accommodation in the hostel. The problem of unemployment among disabled people in the mid-1950s was considerable and was primarily a question of unenlightened attitudes on the part of employers and of ignorance of the scale of the situation. Once again the Fellowship, through its work in Newcastle, promoted the welfare of its members by demonstrating that many of them were fully capable of work and had the capacity to become reliable long-term employees.

Employees eventually gained an understanding of life in the workplace and also provided the project managers with the information with which to write an accurate testimonial to offer to a potential new employer. As well as offering training and work experience to polio-disabled people, the Newcastle project acted as a resource for the whole organisation in producing printed materials, posters, and similar items.

Indeed, the Newcastle project was another great success for the Fellowship; it demonstrated that disabled people were able to be trusted and reliable employees and the project, quite likely, has contributed to improved attitudes in Britain to the employment, training, and education of disabled people. The employees of the project gained considerable benefit many of them openly acknowledging that their success in the job market - and perhaps in society as a whole- is largely the result of the time they spent at Newcastle.

\section{Branches}

The Fellowship, over seventy-plus years of history has involved many people both disabled and able-bodied. The name has changed as the understanding of the disease has changed and now we speak of the British Polio Fellowship. There have been many achievements since 1939, only those of, perhaps, national significance are recorded here. At a more-personal level much work has gone on. 
Right from the very start it was realised that the Fellowship could not possibly achieve all that it wanted to do by being based solely in London; it was necessary to become a national organization and this would mean the formation of local branches ${ }^{54}$. The idea of a local branch seems to have taken the founders and the «London members» rather by surprise but they soon saw the wisdom of the approach. The first branch of the Fellowship was formed in April 1946 in Reading, Berkshire, and was soon followed by a branch in Mansfield, Nottinghamshire. Eventually, the Fellowship branch and group (smaller branches) structure was to develop until there were nearly a hundred local outposts of the Fellowship. Virtually all the work in the branches was undertaken by volunteers although some larger branches employed a secretary or organiser, often on a part-time basis. The existence of 36 branches or groups with more than 16,000 members in $1956^{55}$, demonstrates the important dissemination of the BPF in Britain.

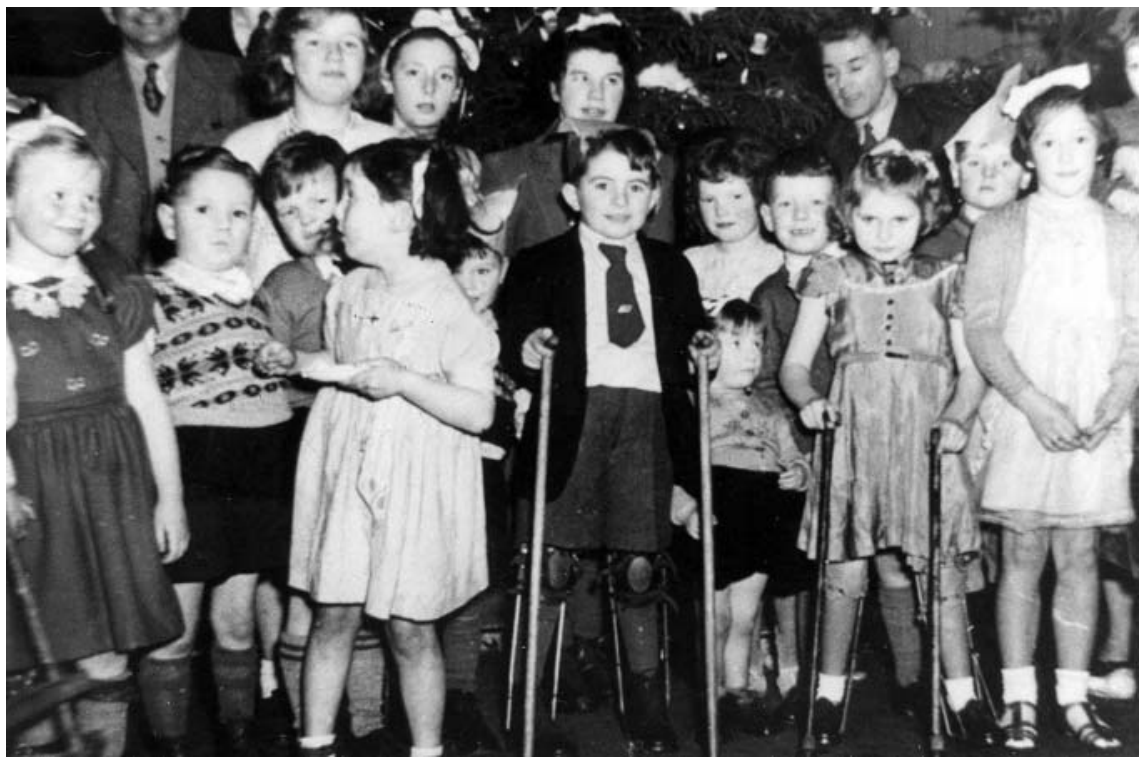

Figure 10. Children of the BPF branch at a Christmas party. Source: British Polio Fellowship Archive.

54. North, n. 3, p. 26-38.

55. Gould, n. 20, p. 165. 
The branch structure meant that the Fellowship was able to have a very personal relationship with its members. As well as the regular branch meetings and activities there was the vital task of caring for the welfare of its members. The challenges and pressures on polio-disabled people did not suddenly go away when the Fellowship was founded; in fact, the opposite was true. As the Fellowship expanded there developed a greater knowledge and understanding of the privations that some disabled people experience in their daily life. Right from the start Fellowship branches were encouraged to appoint welfare officers, people who would take a personal interest in the matters that affect the lives of members.

The Fellowship has recognised that people have needs, by reason of their disability, that they cannot meet and has, over the years, provided cash grants and other practical assistance. This work has generally gone on in a quiet and confidential manner with no-one knowing who is in need and who has been generous with time or money to help another person.

\section{The Bulletin and other records}

Throughout this article much mention has been made of The Bulletin - the newsletter of the Fellowship. First published in 1939 and still published today, The Bulletin, is a valuable source for the history, activities, and concerns of polio-disabled people over a period of eighty-three years. The very first editions, from 1939 until 1946 have been lost. The 1946 editions were printed on a simple rotary duplicator on foolscap-size paper. Then, with the assistance of Dudley Chapman, a small-format newsletter was produced from 1948 and thereafter a new format on paper of a similar size to today's A4 was published. In the 1970s The Bulletin adopted a «newspaper» style of format; sadly most of the back numbers of The Bulletin from 1970 to 1985 have been lost and that period of the Fellowship's history is unrecorded. Today's Bulletin is published six times each year in full colour and sent to every member of the Fellowship.

Many of the photographs which have appeared in The Bulletin over the years have been retained and now form the main part of the Fellowship's photographic archive. Each edition of today's Bulletin carries an article on an historical aspect of the Fellowship or on life with polio as well as an appeal for members to share their memories and memorabilia; this strategy is valuable in providing more material and information for the Fellowship archive. 
As required by the Charities Act (1993), the Fellowship has produced an Annual Report each year which contains details of the finances of the organization as well as a report of the activities of both the national organisation and of some branches. These Annual Reports, along with other publications of the Fellowship, are now housed in the archive and are a valuable source of historical information.

\section{Post-Polio Syndrome. The late effects of polio and the Fellowship}

The Fellowship's work of developing services for polio-disabled people has continued for over seventy years and some may have thought, say, twenty years ago, that the work would soon be over as polio-disabled people grow older and die and services for disabled people improve. But it is over the past two decades that the existence of Post-Polio Syndrome has emerged. It is now accepted that people who have had polio, even those who are described as having made a «full recovery» from the disease, may experience new and hard-to-explain physical symptoms some thirty to fifty years after the original onset of the disease.

The Fellowship has, in recent years been campaigning for the acceptance of Post-Polio Syndrome and is much-involved in education for both medical professionals and those who have the condition ${ }^{56}$. Indeed, such has been the success of the work to highlight the condition that membership levels of the Fellowship have, in recent years, increased in a manner unseen since the 1950's. New infections by polio in Britain have largely ceased by reason of the use of inactivated vaccine ${ }^{57}$ but the need for the supportive work of the Fellowship continues as many people discover that «an illness» which they had in childhood is having long-term debilitating effects in later life.

The commitment of the BPF is reflected nowadays in providing information not only on the Syndrome and services available to cope with it, but also in taking active part in a national research project in partnership with the Walton Centre for Neurology and Neurosurgery in Liverpool. The study, conducted by the University of Birmingham and funded by

\footnotetext{
56. North, n. 3, p. 105-106.

57. Vaccinations campaigns in UK in comparison to other European countries have been studied by Lindner, Ulrike; Blume, Stuart. Vaccine innovation and adoption: polio vaccines in the UK, the Netherlands and West Germany, 1955-1965. Medical History. 2006: 50 (4): 425-446.
} 
Department of Health, seeks to evaluate the services provided for people with rare long-term neurological conditions, including post-polio syndrome. A part of the study is to ask people with post-polio syndrome to complete a questionnaire about their experiences and views of health and social care. Furthermore, the British Polio Fellowship's Expert Panel assists the Trustees and Management to steer the organisation forward, advises on research and medical topics, underpins the work of the Fellowship and broadens awareness. The group of «experts» includes consultants and health professionals from a variety of fields who interact with people with polio ${ }^{58}$.

\section{Conclusions}

The Infantile Polio Fellowship (now British Polio Fellowship) has represented and still represents today a particular type of organization whose achievements over seventy years have been very important in almost every developmental activity involving disabled people.

The path followed by the organization since its beginnings has been shaped by the personalities of its two founders, Patricia Carey and Frederic Morena. In the 1960s, the Fellowship was the first major organization in Britain that was comprised of disabled people not just for them. It was ahead of its time in the sense that it was an organization run by disabled people themselves and an authentic pioneer. Comparative analysis between BPF and other associations against polio such as the American National Foundation for Infantile Paralysis shows differences in their activities for disabled people due to political, social and cultural factors which shaped the birth and the development of both organizations.

The importance of the Fellowship is not only due to its objective results that have improved the quality of life of people involved in it, but for its contribution to social perceptions and changes in laws in a multi-cultural society that embraces all people no matter how «different» they might be. In this sense, knowledge of this kind of mutual aid organizations can contribute to the study of disability policies in Britain within their historical framework.

58. About Post-Polio Syndrome: http://www.britshpolio.org.uk/PolioSyndrome/About Postpolio. aspx [cited 10 Jan. 2011]. 
The approach adopted by the type of association that we have studied in this paper opens a field of possibilities that would be worth exploring in subsequent studies. On the one hand, the social impact of the BPF and its relations with other associations, organizations and institutions should be analyzed through the systematic revision of complementary sources such as general journalism or local and national administrative archives. Second, given the long history of the Association, the documentation we have in the historical records of the BPF can also serve to deal in greater depth with some aspects not directly and specifically covered here; such as the decision-making mechanisms put in place, the discussions on alternative ways to achieve common aims and, in general, the richness and complexity of an emblematic institution in the history of polio associationism. 